\title{
SEPARATE SPHERES: PROTECTIVE LEGISLATION FOR WOMEN IN PAKISTAN
}

\author{
S. Mullally*
}

\section{INTRODUCTION}

A large part of the legislation in Pakistan relating specifically to the employment of women is protective in nature. The 1973 Constitution assumes that women are in need of protection. ${ }^{1}$ This assumption is reflected in the labour legislation and in the international labour standards that have been adopted by Pakistan. Under this 'protective' approach, the identity of the woman who moves beyond the domestic sphere does not alter. For the purposes of legal regulation, she is still identified as a mother or mother in potentia, protective legislation frequently being justified on the ground of 'protection of the function of maternity'. ${ }^{2}$ The public interest in the protection of the physical well-being of women workers and the protection of the role of motherhood has been held to justify, inter alia, prohibitions on night work for women workers, exclusion from underground work and other work deemed potentially hazardous and compulsory post-natal leave. This study engages in an analysis of state practice in the regulation of women's employment in the public sphere ${ }^{3}$ in Pakistan. Gender-specific protective legislation is examined both in the light of the constitutional guarantee of non-discrimination on the basis of sex (Article 25) and the international labour standards that have been

\footnotetext{
* Lecturer in Law, University of Hull.

${ }^{1}$ Cf. Shrin Munir v. Government of Punjab, PLD 1990 SC 295, per Shafiur Rahman J. p. 312.

${ }^{2}$ See, for example, the ILO Maternity Protection Convention (Revised) 1952, No. 103.

${ }^{3}$ In this paper the concepts of public and private spheres serve to distinguish between paid employment in the formal sector and employment which is outside the scope of legal regulation, in particular, home-work, domestic service and women's unpaid economic activities. This paper does not examine women's economic activities in the informal sector. A detailed analysis of this area would be beyond the scope of this paper. For a useful overview of the issues relating to the regulation of home-work, see G. SCHNEIDER DE VILLEGAS, 'Home work: A case for social protection', in 129 International Labour Review No. 4. (1990). See also ILO, 8 Conditions of Work Digest: Home work No. 2 (Geneva, 1989) and Technical Background Document, Meeting of Experts on the Social Protection of Homeworkers (Geneva, 1-5 October 1990).
}

Asian Yearbook of International Law, Volume 4 (Ko Swan Sik et al., eds.; 90-411-0872-6 ${ }^{\circledR} 1995$ Kluwer Law International; printed in Great Britain), pp. 47-67 
adopted by Pakistan. It becomes clear from this analysis that the protective approach, prevalent in the early legislation adopted by the International Labour Organisation (ILO), remains firmly entrenched within the domestic legal framework.

\section{COMPETING MODELS OF EQUALITY: INTERNATIONAL LEGISLATION REGULATING WOMEN'S EMPLOYMENT}

The prevalence of the ideology of 'separate spheres's at the turn of the century is reflected in the early gender-specific protective legislation adopted, in particular by the International Labour Organisation. This protective approach to women's employment in the public sphere has given way to an equal treatment approach and more recently to attempts to render such gendered differences as continue to exist, 'costless' to the individual women and men involved, that is, though differences between the sexes may yet exist, those differences do not, in themselves, give rise to disadvantaged economic and social conditions. ${ }^{5}$

\footnotetext{
${ }^{4}$ The ideology of separate spheres recognises a woman's legal personhood but assigns her a place different and distinct from that assigned to men. One of the best known expressions of the separate spheres ideology is Justice BRADLEY's concurring opinion in an 1873 U.S. Supreme Court case, Bradwell v. Illinois, which begins with the observation that, "Civil law, as well as nature herself, has always recognized a wide difference in the respective spheres and destinies of man and woman" and concludes that the "paramount destiny and mission of woman are to fulfill the noble and benign offices of wife and mother", 83 U.S. 130, 141 (1873). Within Pakistan it has been used to justify 'special measures' for the protection of women (cf. Article 25 of the Constitution) and the different legal status of women under Islamic laws of evidence, see, for example, the Qanoon-e-Shahadat (Law of Evidence Order) 1984, Ordinance LIV of 1984 or Criminal Law (Third Amendment) Ordinance, 1984.

${ }^{5}$ In outlining what would be required by an approach that would make gender differences 'costless', CHRISTINE LITTLETON looks at the cultural constructions of the 'warrior' and the 'mother' arguing that they are 'gendered complements'. The 'cult of motherhood', she argues, resembles the 'glory of battle' in a number of ways: both occupations involve a lot of unpleasant work, along with a real sense of commitment to a cause beyond oneself .... Both involve danger and possible death. And, of course, the rationale most frequently given for women's exclusion from combat is their capacity for motherhood, C. LITTLETON, 'Reconstructing Sexual Equality' (1987), reprinted in K. BARTLETT and R. KENNEDY (eds.), Feminist Legal Theory: Readings in Law and Gender (1991). To make this gender difference 'costless' then, LITTLETON argues, could mean requiring the government to pay mothers the same wages and benefits as soldiers, or it could also mean encouraging the use of motherhood as a recognised qualification for governmental office.
} 


\subsection{Protection}

The early legislation adopted by the ILO reflects the belief that women's special needs and uniquely female characteristics necessitated the enactment of gender-specific protective legislation in three distinct areas: firstly, night work; secondly, underground and other potentially hazardous work; and thirdly, maternity.

\subsubsection{Night Work}

At the first session of its General Conference in 1919, the ILO adopted the Night Work (Women) Convention (No. 4). This was revised and modified in 1934 and 1948. Under the Convention, women are prohibited from working, in any public or private industrial undertaking, other than one in which only members of the same family are employed, between the hours of 10.00 p.m and 7.00 a.m. Exceptions are created for (a) women holding responsible positions of a managerial or technical character; and (b) women employed in health and welfare services, not ordinarily engaged in manual work. ${ }^{6}$ The need to protect the welfare of the family unit was one of the main arguments put forward at the time of the enactment of the Convention. It was also argued that women suffered the negative effects of night work to a greater extent than men because of their additional roles as housewives and mothers. ${ }^{7}$

\subsubsection{Underground and other hazardous work}

Also at its first session, the General Conference adopted the Lead Poisoning (Women and Children) Recommendation, 1919 (No. 4), urging the prohibition of the employment of women and young persons in a number of specific processes and the regulation of their employment in other processes. These restrictions were justified on the basis that such work would involve a danger to the 'function of maternity'. Various other ILO instruments regulate the employment of women, particularly pregnant and nursing women, in specific processes. These include the 1921 White Lead (Painting) Convention

\footnotetext{
${ }^{6}$ Article 8.

${ }^{7}$ See generally, G.A. JoHNSTON, The International Labour Organisation (1970) 224 and Report of the ILO Committee of Experts, Equal Opportunities and Equal Treatment for Men and Women in Employment (Geneva, 1985).
} 
(No. 13); the 1960 Radiation Protection Recommendation (No. 114); the 1967 Maximum Weight Convention (No. 127) and the 1971 Benzene Convention (No. 136). The 'arduous character' of underground work and the 'abuse in the employment of women in mines' led to the adoption in 1935 of the Underground Work (Women) Convention (No. 45), prohibiting the employment of women underground. Again a woman's perceived 'special needs' and presumed physical incapacities were held to justify her exclusion from particular types of work.

\subsubsection{Maternity}

A consideration of the problem of maternity benefits by the General Conference at its first session gave rise to the 1919 Maternity Protection Convention (No. 3). It provided a number of important benefits for pregnant women and nursing mothers, regardless of marital status. These included paid leave before and after childbirth, including compulsory postnatal leave of no less than six weeks (Articles 3 and 4), job protection during such leave (Article 6) and nursing on the job "at times prescribed by national laws or regulations" (Article 3). The original Convention was expanded and modified in 1946 and again in 1952. The revised Convention (No. 103) is wider in scope as it applies also to women employed in non-industrial and agricultural occupations, women wage earners working at home and to domestic workers. ${ }^{8}$

The prevalence of the 'special treatment' approach can be seen here in the treatment of pregnancy as a unique biological condition and in the concern for the protection of the role of motherhood through the imposition of compulsory postnatal leave of at least six weeks, regardless of individual women's actual needs or requirements following childbirth.

\subsection{Equal Treatment}

The adoption of the Discrimination (Employment and Occupation) Convention (No. 11) in 1958 appeared to mark a movement away from the earlier protective treatment approach. Under the terms of the Convention, each member agrees to declare and pursue a national policy designed to promote

\footnotetext{
${ }^{8}$ The 1921 Maternity Protection (Agriculture) Recommendation (No. 12) had invited member states to take measures to ensure to agricultural workers protection before and after childbirth similar to that provided for women employed in industry and commerce.
} 
equality of opportunity and treatment. However, gender-specific protective legislation does not fall within the scope of discrimination as defined by the Convention. ${ }^{9}$ Article 5, paragraph 1 of the Convention states: "Special measures of protection or assistance provided for in other Conventions or Recommendations adopted by the International Labor Conference shall not be deemed to be discrimination". This provision endorses, without qualification, the protective measures earlier adopted by the ILO. ${ }^{10}$ While the definition of discrimination contained in Article 1 suggests the adoption of an equal treatment approach, the provisions that follow recall the protective spirit of earlier ILO standards without any precise limitation being set on the nature of protective measures considered to be permissible. In addition, paragraph 2 of Article 5 states, "Any member may [. . .] determine that other special measures designed to meet the particular requirements of persons who, for reasons such as sex, age, disablement, family responsibilities or social or cultural status, are generally recognized to require special protection or assistance, shall not be deemed to be discrimination". The underlying assumption, again, is that women are in need of special protection because of their 'particular requirements'. Even more disturbing, however, is the reference to reasons such as "family responsibilities, or social or cultural status" as justifying the enactment of gender-specific protective measures. The very pervasiveness of social and cultural assumptions concerning women's proper roles and responsibilities that serve to hinder women's participation in the workplace, and which it is the stated objective of this Convention to eliminate, is held to justify further restrictions on women's employment.

The last fifteen years or so, however, has seen substantial inroads being made into the protective approach so prevalent in early legislation regulating women's employment. The ILO Workers with Family Responsibilities Convention (No. 156) and Recommendation No. 165 adopted in 1981, tackle the particlar problems of workers with family responsibilities. Both the Recommendation and the Convention recognize the need to alter the structure of the market-place in order to render any differences that may arise as a result of family responsibilities 'costless' to the individual women and men involved. The need for a reallocation of burdens and responsibilities within the familial sphere to enable women to participate on an equal footing with men in the marketplace is also admitted. Differences between workers are perceived as

\footnotetext{
${ }^{9}$ Article 1 defines discrimination as, "[. . . ] any distinction, exclusion or preference made on the basis of race, color, sex, religion, political opinion, national origin, which has the effect of nullifying or impairing equality of opportunity or treatment in employment or occupation".

${ }^{10}$ See, for example, the 1948 Night Work (Women) Convention (No. 89) and the 1935 Underground Work (Women) Convention (No. 45) discussed above.
} 
arising from the family responsibilities of both women and men, rather than as inhering in women themselves, because of the 'uniqueness' of their procreative functions or the primacy of the role of motherhood. The adoption of the Convention represents a significant advance beyond the earlier Employment (Women with Family Responsibilities) Recommendation (1965, No. 123).

Criticisms of the prohibition on night work for women eventually led, after a great deal of acrimonious debate, to the adoption by the ILO of the Protocol of $1990^{11}$ which sought to bring greater flexibility to the standards governing night work for women. The Protocol allows for variations in the duration of the night period and for exemptions from the prohibition for night work. However, no variation or derogation is permitted during a period of at least 16 weeks before and after childbirth, of which at least eight weeks must be before the expected date of delivery. The Protocol is a compromise between the conflicting opinions expressed by states. Under the present legal framework those states wishing to maintain the prohibition on night work for women may do so, although greater flexibility in the application of the prohibition is expected, while those wishing to remove the prohibition may proceed, with certain provisos concerning the health and safety of workers.

The adoption in 1979 of the UN Convention on the Elimination of All Forms of Discrimination Against Women further accelerated the demise within international law of the protective approach to women's participation in the public sphere. The requirement in Article 5 of the Convention that States Parties take steps "to modify social and cultural patterns of conduct of women and men" recognizes that differences are often created by contingent social and political structures rather than inhering in women and men themselves. The adoption of "temporary special measures" aimed at correcting inequalities that may have arisen because of such contingent social structures is permitted under Article 4. Indeed, the Convention has been interpreted by some commentators as imposing a duty on States Parties to take special measures or to create affirmative action programs. ${ }^{12}$ The Committee on the Elimination of Discrimination Against Women which was established to monitor the implementation of the Convention, has reiterated the importance of this obligation in its general recommendations. In particular, it has recommended that States Parties:

\footnotetext{
"Protocol of 1990 to the 1948 Night Work (Women) Convention (Revised).

${ }^{12}$ See, for example, A. BAYEFSKY, 'The Principle of Equality or Non-Discrimination in International Law', 11 Human Rights Law Journal (1990) at 27.
} 
"[. . .] make more use of temporary special measures such as positive action, preferential treatment or quota systems to advance women's integration into education, the economy, politics and employment." ${ }^{13}$

This is in line with the position adopted by the Human Rights Committee under the ICCPR that " [ . . .] as long as such action is needed to correct discrimination in fact, it is a case of legitimate differentiation under the Covenant". ${ }^{14}$ Special measures for the protection of maternity are also permitted under the Convention. However, strict limitations are placed on the scope of their permissible operation. The Preamble to the Convention explicitly states that the role of women in procreation should not be a basis for discrimination. This is reiterated in Article 11 paragraph 2 which addresses itself specifically to discrimination on the grounds of marriage or maternity. States Parties are required to make provision for maternity leave and to take such measures as are necessary for the health and safety of women workers during pregnancy. However, such measures must be reviewed periodically in the light of scientific and technological knowledge and revised as necessary. States are also required to safeguard the reproductive capacities of male workers. Article 11.1 (f) refers to the right to protection of health and to safety in working conditions, including "the safeguarding of the function of reproduction", thus highlighting the arbitraryness of gender-specific protective legislation which seeks only to protect women's reproductive functions. The reference in the Preamble to the great contribution of women to the welfare of the family and to the need for a "proper understanding" of maternity as a "social function" represents a move towards a positive valuation of the work and roles traditionally undertaken by women without attempting to restrict women's access to the public sphere on that basis. The requirement in Article 11.2(c) that adequate child care facilities and supporting social services be provided is an attempt to ensure that whether or not child care responsibilities continue to be divided along gender lines, those responsibilities should not restrict women's participation in the workforce.

Pakistan is party to the 1948 ILO Night Work (Women) Convention (Revised) and the 1935 Underground Work (Women) Convention. The Convention on Maternity Protection, however, has not yet been adopted. Although Pakistan has ratified the 1958 Convention on Discrimination in Employment and Occupation, later standards which move away from the protective

\footnotetext{
13 7th session, 1988, A/43.38 (1988) 109.

${ }^{14}$ CCPR/C/21/Rev.1/Add.1 para.10, adopted by the Human Rights Committee under Article 40(4) of the ICCPR at its meeting of 21 November 1989 and reproduced in its Annual Report A/45/40.
} 
approach to women's employment in the public sphere have not been adopted. It has not yet signed the Protocol of 1990 providing for greater flexibility in women's participation in night work, neither is it a party to the 1981 Workers with Family Responsibilities Convention or the 1979 UN Women's Convention. ${ }^{15}$ The failure to follow the trend in international law towards equal treatment is also reflected in the protective approach to women's participation in the workforce prevalent in constitutional doctrine and domestic labour legislation.

\section{EQUALITY AND NON-DISCRIMINATION UNDER THE 1973 CONSTITUTION}

Competing and often conflicting models of equality are found within the 1973 Constitution. While on the one hand, exhorting the State to take steps "to ensure full participation of women in all spheres of national life" (Article 34), on the other hand, it clearly entrenches within the legal sphere, the notion of 'separate spheres' for women and men, presuming that women and not men are in need of protection when they enter into the public sphere. Article 25 is a general guarantee of "equality before law" and "equal protection of the law" for all citizens. ${ }^{16}$ It is an autonomous or free-standing equality norm, which means that equality before the law and equal protection of the law are guaranteed in themselves and not merely in the context of a threat to other fundamental rights enshrined within the Constitution. According to PIRZADA, equality before the law is a "somewhat negative concept implying the absence of any special privilege in favour of an individual and the equal subjection of all classes to the ordinary law", whereas "equal protection of the laws is a more positive concept implying equality of treatment in equal circumstances". ${ }^{17}$ Both phrases are aimed at the prohibition of arbitrary distinctions only. Not all differences in treatment will be held to be discriminatory and equal treatment does not mean that all persons should be treated in the same manner. As KAIKUS J. has put it, "All law implies classification for when it applies to a set

\footnotetext{
${ }^{15}$ India, which has an almost identical constitutional guarantee of equality, has signed (on the 30th July 1980) but not yet ratified the UN Women's Convention. Neither has it adopted the 1981 Workers with Family Responsibilities Convention or the 1990 Protocol on Night Work for Women.

${ }^{16}$ Clause (1) of Article 25 is identical to Article 15 of the Constitution of 1962 and clause (1) of Article 5 of the 1956 Constitution. Clauses (2) and (3) of Article 25 are new.

17 Syed Sharifuddin PIRZADA, Fundamental Rights and Constitutional Remedies in Pakistan (1966) 365. See also Hiralal Sutwala v. State, AIR 1953 Nag. 58.
} 
of circumstances, it creates thereby a class, and equal protection means that this classification should be reasonable". ${ }^{18}$ Thus the doctrine of reasonable classification has developed in response to the need to distinguish those differences in treatment that may be justified from those which are 'palpably arbitrary' ${ }^{19}$ In Jibendra Kishore v. Province of East Pakistan, ${ }^{20}$ MUNIR C.J. argued that classification of persons or things is in no way repugnant to the equality doctrine provided the classification is not arbitrary or capricious, is natural and reasonable and bears a fair and substantial relation to the object of the legislation. ${ }^{21}$ The doctrine of reasonable classification then, has two key requisites: (a) The classification must be reasonable and should not be arbitrary or capricious; and (b) there must be a reasonable relationship of proportionality between the object of the legislation and the classification employed to attain it. This definition of "reasonable classification" is in keeping with the line drawn by international law between unjustified and justified distinctions. The preliminary point is made, by both the European Court of Human Rights and the Human Rights Committee, that not all differences in treatment are discriminatory or that equal treatment does not mean the same treatment. ${ }^{22}$

The question relevant to us here is whether classification on the basis of sex may be deemed to be "arbitrary or capricious". The question is pre-empted somewhat by the wording of Article 25 itself. Article 25(2) prohibits discrimination on the basis of sex alone. However, the very next clause (3) substantially qualifies the preceding paragraphs. It provides that, "[n]othing in this article shall prevent the State from making any special provision for the protection of women and children". Thus, it creates an exception in favour of women and children, inasmuch as any special provision for their protection

${ }^{18}$ Progress of Pakistan Co. Ltd. v. Registrar, Joint Stock Companies, Karachi, PLD 1958 Lah., p. 906.

${ }^{19}$ Abdul Akbar Khan v. D.C. Peshawar, PLD 1957 Pesh. 100.

${ }^{20}$ PLD 1957 SC 9.

${ }^{21}$ Ibid., at 38.

${ }^{22}$ In the Belgian Linguistics Case, decided in 1968, the European Court of Human Rights stated: "[T]he principle of equality of treatment is violated if the distinction has no objective and reasonable justification. The existence of such a justification must be assessed in relation to the aim and effects of the measure under consideration, regard being had to the principles which normally prevail in democratic societies. A difference in treatment in the excercise of a right laid down in the Convention must not only pursue a legitimate aim: Article 14 [the prohibition of discrimination on any ground, including, inter alia, sex, race, colour etc.] is likewise violated when it is clearly established that there is no reasonable relationship of proportionality between the means employed and the aim sought to be realized" (Case Relating to Certain Aspects of the Laws on the Use of Education in Belgium (Merits), 23 July 1968, Volume 6, Series A, European Court of Human Rights, paragraph 10). 
may not be interpreted as gender-based discrimination. ${ }^{23}$ Special measures for the protection of women then, are permissible. This raises two issues: (1) What constitutes a special measure consistent with the principle of equality or non-discrimination; and (2) Are special measures for the protection of women mandatory or is paragraph (3) merely an enabling clause?

(1) In Shrin Munir and others $v$. Government of Punjab, ${ }^{24}$ a case concerning the use of quotas for girl students applying for admission to medical college, SHAFIUR REHMAN, J. argued: "While the difference on the basis of sex can be created and maintained, it shall be done only in those cases where it operates favourably as a protective measure for and not against women and children" ${ }^{25}$ The test to be applied to determine the constitutionality of protective legislation for women is whether it operates favourably for women. No clear criteria are suggested to assist in the determination of this question. However, SHAFIUR REHMAN does state that it is dangerous to proceed on the basis of "general nebulous assertions" and "factual" conclusions unsupported by scientific study or appropriate data. ${ }^{26}$ It would seem from the judgement given by Justice SHAFIUR REHMAN, that in making such an assessment relevant scientific studies and appropriate data would have to be taken into account. This would be in line with the requirement in the Women's Convention that all protective legislation applying to women be reviewed in the light of up-todate scientific knowledge and technical changes.

(2) MUHAMMAD MUNIR argues that the fundamental rights contained in the 1973 Constitution of Pakistan, which are expressed by a negative command (the State shall not make any law), must be interpreted only as restrictions on legislation. ${ }^{27}$ In contrast, however, he argues that the Principles of Policy that have mostly been stated in a positive form, ought to be considered as positive objects of legislation and thus principles of law-making. ${ }^{28}$ Of particular

${ }^{23}$ Muhammad AfZal Lone J. explains the import of Article 25 thus:

Article 25(1) [. . .] is a general equality clause, which negates arbitrary power and extends Fundamental Right of equality before law and equal protection of law to all citizens. SubArticle (2) prohibits discrimination on the basis of sex alone, to which sub-Article (3) creates an exception in favour of women and children, inasmuch as any special provision for their protection, is not an affront to gender-based discrimination [. . . ]

Government of Punjab (Health Dept.) v. Naila Begum, p. 358.

${ }^{24}$ PLD 1990 Supreme Court 295.

${ }^{25}$ Ibid., 309.

${ }^{26}$ Ibid., 312.

${ }^{27}$ M. MUNIR, Constitution of the Islamic Republic of Pakistan (1975) 64.

${ }^{28}$ Ibid., 216. 
relevance to us here are Articles 34, 35 and 37(e). Article 34 provides that, "Steps shall be taken to ensure full participation of women in all spheres of national life", suggesting a positive duty on the State to establish affirmative action programs. Articles 35 and 37(e) provide respectively that: the State shall protect the marriage, the family, the mother and the child; and the State shall make provision for securing just and humane conditions of work, ensuring that children and women are not employed in vocations unsuited to their age or sex, and for maternity benefits for women in employment, suggesting a positive duty on the State to take special measures for the protection of women. The Principles themselves, however, are not rules of law, their true position having been determined by Article 30 which provides that the validity of an action or of a law shall not be called in question on the ground that it is not in accordance with the Principles of Policy and no action shall lie against the State or any person on such ground. ${ }^{29}$ Thus, while these provisions clearly mandate the existence of an ongoing process of development, objective scrutiny of any such process is excluded. The Principles of Policy then, may be interpreted as guiding principles only, directive in nature and always "subject to the availability of resources" (Article 29(2)). Neither Article 25 nor the Principles of Policy may be interpreted as imposing a strict legal obligation on the State to take special measures for the protection of women workers or to create affirmative action programs. Rather, they are enabling provisions only, conferring on the State a discretionary power to take action. At best, the Principles of Policy may be interpreted as imposing an obligation of conduct on the State, that is, an obligation on all organs of the State and all persons acting on behalf of the State to keep the principles in view while so acting. ${ }^{30}$ This falls far short of the interpretation given to the equality guarantees in both the Women's Convention and the ICCPR, where States are held to have a duty to adopt special measures to eliminate de facto inequalities between women and men.

The test of the constitutionality of any legislation specifically affecting women is whether or not it operates in their favour. This, however, does not exclude claims that women's 'natural' sex differences or different sex roles necessitate special measures regulating their participation in the workforce and given that protective measures are specifically sanctioned by Article 25 and by the international labour conventions to which Pakistan is a party, it is unlikely

\footnotetext{
${ }^{29}$ See Muhammad Saddiq v. Commissioner, Lahore Division, PLD 1962 Lah. 999.

${ }^{30}$ In the words of A.K. BROHI: "These provisions then constitute the manifesto of the policies and programs of the State [. . . ] and are required to be kept in view by subsequent generations so as to secure continuity in the maintenance of a homogeneous and consistent policy in the matter of handling the affairs of the State". A.K. BROHI, Fundamental Law of Pakistan (1958) at 313.
} 
that protective legislation would be held in violation of the constitutional guarantee of equality.

\section{DOMESTIC LEGISLATION RELATING TO WOMEN WORKERS}

Domestic legislation referring specifically to women's participation in paid employment is highly protective in nature. Much of it is a legacy of the colonial period and reflects the concerns of the early factory movement to protect women's roles within the domestic sphere and, in particular, to protect the actual and possible offspring of women workers. In line with international labour standards, protective measures have been adopted in relation to night work, underground and other potentially hazardous work and maternity.

\subsection{Night Work}

Night work for women in Pakistan is regulated by the 1934 Factories Act. ${ }^{31}$ Under the Act women may only be employed in factories ${ }^{32}$ between the hours of $6.00 \mathrm{a} . \mathrm{m}$. and $7.00 \mathrm{p} . \mathrm{m} .{ }^{33}$ The stated purpose of section 45 of the Factories Act was to secure a night rest of not less than 11 hours for women, in accordance with the recommendations made in the 1931 Report of the Royal Commission on Labour in India ${ }^{34}$ and the international labour standards laid down in the 1919 Night Work (Women) Convention (No. 4). However, although the Commission had taken the stance that factory working

\footnotetext{
${ }^{31}$ Act No. XXV of 1934.

${ }^{32}$ The definition of factory as given in the 1934 Factories Act is as follows: "Factory means any premises, including the precincts thereof, whereon twenty or more workers are working, or were working on any day of the preceding twelve months, and in any part of which a manufacturing process is being carried on with the aid of power, or is ordinarily carried on, but does not include a mine subject to the operation of the Mines Act, 1923".

${ }^{33}$ Factories Act 1934 section 45, sub-section (1)(b). Section 45 replaced section 24 of the 1911 Factories Act (Act XII) which provided that, “(a) no woman shall be employed in any factory before half-past five o'clock in the morning or after seven o'clock in the evening; (b) no women shall be employed in any factory for more than eleven hours in any one day".

${ }^{34}$ See the Statement of Objects and Reasons and Notes on Clauses, Gazette of India Part V (1933) 178. The Royal Commission was appointed in 1929 in order to enquire into and report on the existing conditions of labour in industrial undertakings and plantations in British India and, in particular, to report on the health, efficiency and standard of living of the workers. Report of the Royal Commission on Labour in India (Whitely Commission Report, 1931), extracts reproduced in Prem Nath Chadha and AshoK Kumar Kuba (eds.), Encyclopedia of Labour Laws and Industrial Legislation, Vol. 1 (1955).
} 
hours were excessive, it concluded that to restrict women by law to shorter hours than men would lead to the "highly undesirable situation" whereby male workers would be substituted for women workers in many factories. The better policy, wherever possible, they argued, was to fix hours that were reasonable for adults of both sexes. Thus, it was hoped to avoid a course of action which would be likely to unnecessarily prejudice the work of women and to disorganise industries where the processes performed by men and those performed by women were interdependent. It is interesting to note how similar the opinion of the Commission is, to the recent standard setting measures on night work taken by the ILO. The Commission proposed to extend the period within which factories could employ women from thirteen and a half to seventeen hours, although the period within which any individual woman could be employed was to be reduced from 13 and a half to 13 hours. Although the latter part of the proposal was accepted ${ }^{35}$ the recommendation to extend the period within which women could be employed was strongly criticized and was not incorporated into the 1934 Act. $^{36}$

Exceptions to the prohibition on night work are permitted where the factory is a seasonal one or "where the employment of women beyond the said hours is necessary to prevent damage to or deterioration in any raw material". ${ }^{37}$ The prohibition on night work is narrower in its scope of application than that contained in the 1948 Night Work (Women) Convention. ${ }^{38}$ Whereas under domestic law, night work is prohibited only in factories specifically defined as "any premises [. . .], whereon twenty or more workers are working", an "industrial undertaking" as defined in the Convention does not specify any minimum number of workers. Greater flexibility in the implementation of the prohibition is permitted by the Convention. Night, for example, is defined as a period of at least 11 consecutive hours, including an interval of at least seven consecutive hours, falling between 22.00 p.m. and

\footnotetext{
${ }^{35}$ A new section 45 (1) was inserted providing that the Provincial Government could, by notification, vary the limits laid down in clause (b) to any span of thirteen hours between the hours of 5 a.m. and 7.30 p.m. (this was subsequently amended by section 6 of the 1946 Factories (Amendment) Act.

${ }^{36}$ See Notes on Clauses (Factories Act 1934) loc. cit. n. 34.

${ }^{37}$ Factories Act 1934 section 45 sub-section (2). Under the Export Processing Zones (Control of Employment) Rules a general exemption from the provisions of the Factories Act, including the prohibition on night work for women, has been granted to all Export Processing Zones. See Export Processing Zones (Control of Employment) Rules, in Gazette of Pakistan, Extra (Islamabad), 10 October 1982, Part II. See generally, D.M. DROR, 'Aspects of labour law and relations in selected export processing zones', 123 International Labour Review No. 6 (1984) at 705.

${ }^{38}$ Pakistan ratified the Convention on 2 February 1951.
} 
07.00 a.m. (Article 2), thus allowing for greater flexibility than domestic law which specifically prohibits women from working between the hours of 7.00 p.m. and 6.00 a.m. Article 6 of the Convention is a catch-all provision permitting the night period to be reduced to ten hours on sixty days of the year in industrial undertakings that are influenced by the seasons and in all cases where "exceptional circumstances" demand it (Article 6). The variations permitted by domestic law are clearly in line with those permitted by the Convention although the sixty day limit imposed is not reproduced. An additional variation, not found in domestic law is the provision in Article 7 of the Convention that in countries where the climate renders work by day "particularly trying", the night period may be shorter than that prescribed if compensatory rest is accorded during the day. The attempt by the ILO to introduce further flexibility into the regulation of night work by enacting the Protocol of 1990 has not yet been followed by Pakistan. However, given the compromising stance taken in the Protocol, its adoption by Pakistan would not necessarily require any changes in domestic legislation.

\subsection{Hazardous to Health}

A woman's perceived special needs and presumed physical incapacity is held to justify her exclusion from types of employment deemed hazardous to health. The 1934 Factories Act prohibits the employment of women on or near machinery in motion, ${ }^{39}$ and further prohibits the employment of women in any part of a factory for pressing cotton in which a cotton-opener is at work. ${ }^{40}$ It also contains an enabling clause permitting Provincial Governments to enact rules prescribing the maximum weights that may be lifted, carried or moved by adult women, adolescents and children.$^{41}$ Under the 1963 Hazardous Occupation Rules the employment of women is prohibited in a number of specific processes involving, inter alia, the use of lead, rubber, chromium, and

\footnotetext{
${ }^{39}$ Section 27(2) provides that, "no woman or child shall be allowed in any factory to clean, lubricate or adjust any part of machinery while that part is in motion, or to work between moving parts or between fixed and moving parts of any machinery which is in motion". This provision is repeated in the 1978 Punjab Factories Rules (Appendix III, Rule 134, section 31), the 1975 Sind Factories Rules (Appendix III, Rule 121, section 31) and also in the 1975 NWFP Factories Rules (Appendix III, Rule 131, section 31).

401934 Factories Act section 32.

${ }^{41}$ Section 33-F, sub-section 2. See section 78 of the 1978 Punjab Factories Rules which prescribes the maximum weights that a woman, adolescent or child may lift.
} 
sand-blasting. ${ }^{42}$ A blanket prohibition on the employment of women "in any part of a mine that is below ground" was introduced by the 1973 Mines (Amendment) Act. ${ }^{43}$ Exemptions are permitted in respect of women holding positions of a managerial or technical character or employed in health and welfare services and not ordinarily performing manual work. This provision is slightly narrower in scope than that contained in the corresponding ILO Convention which includes female students engaged in training underground within the scope of possible exemptions (Article 3). Otherwise domestic law conforms to the requirements of the Convention.

\subsection{Maternity}

Maternity Protection for women is governed by:

(i) the West Pakistan Maternity Benefit Ordinance, $1958^{44}$ (hereinafter the $\mathrm{MBO}$;

(ii) the West Pakistan Maternity Benefit Rules, $1961^{45}$; and

(iii) the Provincial Employees Social Security Ordinance, 1965 (hereinafter, the PESSO). The PESSO makes provision for maternity benefit but does not contain general provisions relating to protection during maternity.

The laws governing maternity protection apply only to specific categories of female employees and are of much more limited scope than the 1952 ILO Convention on Maternity Protection. The MBO is applicable only to factories, as defined by the 1934 Factories Act, ${ }^{46}$ including places declared to be factories under section 5 of the Act, ${ }^{47}$ but not including seasonal factories.

\footnotetext{
${ }^{42}$ See: the 1963 West Pakistan Hazardous Occupations (Lead) Rules, section 5; the 1963 (Rubber) Rules section 3; the 1963 (Chromium) Rules, section 3; the 1963 (Sand Blasting) Rules section 4 and the 1963 (Petrol Gas Generating Plant) Rules, section 3.

${ }^{43}$ Act XLV of 1973, section 23-C.

${ }^{44}$ West Pakistan Maternity Benefit Ordinance No. XXXII of 1958.

${ }^{45}$ See Gazette of West Pakistan Extr. 10 June 1961, p. 1505. The West Pakistan Maternity Benefit Rules, 1961 include provisions: (a) delineating the powers of the Director of Labour Welfare and of Inspectors; (b) prescribing the method of payment of maternity benefit; and (c) outlining the procedures governing appeals to the Director of Labour Welfare.

${ }^{46}$ Op. cit. n. 31 .

${ }^{47}$ Section 5 of the Factories Act, 1934, provides:

the Provincial Government may, by notification, declare that all or any provisions of this Act may apply to any place wherein a manufacturing process is being carried on or is ordinarily carried on whether with or without the use of power whenever five or more workers are working therin or have worked therin on any one day of the twelve months immediately preceding.
} 
This legislation suffers from the restricted scope and level of protection typical of employers liability measures. The PESSO is specifically designed for gradual application and applies, therefore, only to "such areas, classes of persons, industries or establishments, from such date/dates and with regard to the provisions of such benefits" as are notified by the Federal Government. ${ }^{48}$ Women employed in agricultural occupations or wage earners working at home are outside the scope of maternity protection.

The requirements regarding maternity leave contained in the ILO Convention are the same as those laid down under domestic law, that is twelve weeks maternity leave at least six of which must be taken as post-natal leave. The concern for the protection of the role of motherhood is again evident in the imposition of compulsory post-natal leave. ${ }^{49}$

Little or no provision is made for nursing mothers. The Factories Act contains only an enabling clause permitting provincial governments to enact rules requiring that a suitable room be reserved for the use of nursing children under the age of six and prescribing the health and safety standards for such rooms, in any specified factory wherein more than fifty women are ordinarily employed. ${ }^{50}$ No specific provision is made for nursing mothers to interrupt their work for the purpose of nursing. This falls short of the ILO Maternity Protection Convention which states that times should be specified in national laws or regulations to allow nursing mothers to interrupt their work.

Both the MBO and the PESSO make provision for the payment of cash benefits for a twelve week period..$^{51}$ However, eligibility for maternity benefit is restricted. Under the MBO a woman is only entitled to maternity benefit if she has been employed in the factory of the employer from whom she is claiming for a minimum period of four months immediately preceding the date of delivery. ${ }^{52}$ The PESSO provides that a "secured" woman $^{53}$ is entitled to

\footnotetext{
${ }^{48}$ Export processing zones have been specifically excluded from the provisions of the PESSO. Neither are they subject to the provisions of the Maternity Benefit Ordinance.

${ }^{49} \mathrm{MBO}$ section 3 \& section 4; PESSO section 36.

so 1934 Factories Act, section 33-Q. See also section 94 of the 1975 Sind Factories Rules; section 92 of the 1978 Punjab Factories Rules and section 92 of the 1975 NWFP Factories Rules, all of which have been enacted pursuant to section 33-Q.

${ }^{51}$ PESSO section 36.

$52 \mathrm{MBO}$ section 4 . The four month period was substituted for nine months by the West Pakistan Act No. XVIII of 1967.

${ }^{53}$ PESSO section 2(25); 'secured person' means a person in respect of whom contributions are or were payable under this Ordinance. Contributions are payable in respect of all employees defined in section 2(8) as, "any person working, normally for at least twenty-four hours per week, for wages, in or in connection with the work of any industry, business, undertaking or establishment, under any contract of service or apprenticeship [ . . .]".
} 
receive maternity benefit if contributions in respect of her were paid or payable for not less than one hundred and eighty days during the twelve calendar months immediately preceding the expected date of her confinement. Although this is common practice in many states no such minimum requirement is laid down by the ILO Convention. Apart from the requirements laid down in the PESSO, no provision is made for medical benefits for pregnant women. The PESSO imposes a duty on employers to provide pre-natal and post-natal medical care not only to women entitled to maternity benefit, but also to any woman in respect of whom contributions were paid or payable, for not less than ninety days during the six calendar months immediately preceding a claim. ${ }^{54}$ No mention of medical benefits is found in the MBO. This falls far short of the Convention which imposes an obligation on all employers to provide pre-natal and post-natal care by qualified midwives or medical practitioners as well as hospitalisation where necessary (Article 4).

Only limited protection is provided under the ILO Convention: dismissal during the period of maternity leave is prohibited (Article 6), however, no express reference is made to dismissal on grounds of pregnancy. Similarly under domestic law, although a notice of dismissal may not be served on a female employee while she is on maternity leave, ${ }^{55}$ again, no express reference is made to dismissal on grounds of pregnancy. A notice of dismissal given "without sufficient cause" to a female employee, within a period of six months before the date of delivery, cannot have the effect of depriving her of any maternity benefit to which she would otherwise have been entitled. ${ }^{56}$ Dismissal on grounds of pregnancy is not itself recognised as giving rise to any other cause of action. Neither is there any clear guarantee of a right to return to work after maternity leave.

Under the MBO any woman who engages in work for which she receives payment, in cash or kind, during the twelve week period of maternity leave, may be subject to a fine. ${ }^{57}$ She may also forfeit her right to any maternity benefit not already paid to her. Any employer found to be contravening the MBO may be subjected to a fine ${ }^{58} \mathrm{~A}$ court may order the whole or any part of any such fine to be paid as compensation to the woman concerned, where the contravention in question has resulted in her being deprived of maternity benefit. $^{59}$

\footnotetext{
${ }^{54}$ Ibid., section 38 .

${ }^{55} \mathrm{MBO}$ section 7(1)(a).

${ }^{56} \mathrm{MBO}$ section 7(1)(b).

${ }^{57} \mathrm{MBO}$ section 8.

${ }^{58} \mathrm{MBO}$ section 9.

59 Ibid.
} 
Concern to protect the role of motherhood is evident in the imposition of compulsory postnatal leave and in the existence of a penalty to be imposed on women working during the period of compulsory leave. This clearly reflects a concern not to protect the welfare of women workers but to impose a specific allocation of responsibilities within the domestic sphere. It goes much further than the provision made for compulsory post-natal leave in the ILO Convention which does not countenance the possibility of a penalty being imposed on a woman working during that period.

\subsection{Other 'protective' legislation}

The presumption that women are in need of protection is further reinforced by the provisions on distribution of compensation contained in the 1923 Workmen's Compensation Act, ${ }^{60}$ which provide that any payment of a lump sum as compensation "to a woman or a person under legal disability" must be deposited first with the Commissioner ${ }^{61}$ It also provides that where any lump sum deposited with the Commissioner is payable to a woman, such sum may be invested, applied or otherwise dealt with for the benefit of the woman, in such manner as the Commissioner may direct. ${ }^{62} \mathrm{~A}$ woman is perceived as being 'disabled' within the male world of the marketplace and hence in need of the protection of the State, here appearing in the guise of the Commissioner of Workmen's Compensation. This protective approach and the ideology of separate spheres that underlies it, have been reinforced by the measures taken in the name of 'Islamisation'. Although they have not directly targeted women's participation in employment, they have led to a diminution in the legal status of women, "stifling women's voices in the public arena and pushing back the boundaries of social visibility". ${ }^{63}$ The Islamisation process

\footnotetext{
${ }^{60}$ Act No. VIII of 1923.

${ }^{61}$ The term Commissioner here refers to all persons appointed by the Provincial Government as Commissioners of Workmen's Compensation under section 20 of the Act. In accordance with section 23 of the Act, Commissioners posess all the powers of a civil court.

${ }^{62}$ Workmen's Compensation Act, 1923 section 8 sub-sections (1) and (7).

${ }^{63}$ AYESHA JALAL, 'The Convenience of Subservience: Women and the State of Pakistan', in D. KANDIYOTI (ed.), Women, Islam and the State (1991) 77. The first laws introduced by ZIA-ULHAQ in the process of Islamisation were the Hudood Ordinances. Of particular relevance is the Offence of Zina (Enforcement of Hudood) Ordinance, (Ordinance VII of 1979) concerning the crimes of rape, adultery, abduction and fornication. Section 4 of the Ordinance provides that a man and woman commit 'zina' if they wilfully have sexual intercourse without being validly married to each other. Under the Ordinance the evidence of the complainant of rape, or any medical evidence is not admissible. The question of consent on the part of a complainant assumes
} 
received a new impetus under General ZIA. On the assumption of the office of Chief Martial Law Administrator in July 1977, ZIA-UL-HAQ suspended the fundamental rights contained in the 1973 Constitution, ordered that the 1973 Constitution was in abeyance and proclaimed that Islamisation was his prime objective. In particular, he promised to restore the sanctity of the chador aur chardiwari, that is, woman veiled and within the four walls of her house. Control over female sexuality and the preservation of women's modesty was equated with the maintenance of cultural integrity. Thus the struggle over women's autonomy was placed at the centre of the Islamisation process. As one commentator noted, establishing Islamic credentials through retrogressive legislation primarily affecting women was a logical step in a context where the control of women and of their appropriate conduct had long been used to demarcate the identity and boundaries of the Muslim community in the Indian sub-continent. ${ }^{64}$

The Qanoon-e-Shahadat Order of $1984^{65}$ directly impinges on women's participation in the workforce. Art. 17(1) of the Order provides that

"In matters pertaining to financial or future obligations, if reduced to writing, the instrument shall be attested by two men, or one man and two women, so that one may remind the other, if necessary and evidence shall be led accordingly."

The original draft had required the testimony of two men or of one man and two women on all matters. However, following widespread protests from women's rights groups and others, the original provision was watered down and is now applicable only to financial transactions reduced to writing ${ }^{66}$ Here

particular significance. If the court finds that the complainant consented to sexual intercourse, the charge may be converted from one of rape ('zina-bil-jabr') to one of 'zina' (sexual intercourse outside marriage) and the complainant herself becomes the accused. See, for example, NLR 1985 SD 145 Safia Bibi, and PLD 1983 FSC 110 Shabbir Ahmed.

While the Hudood laws do not directly target women in employment, they have greatly contributed to a diminution in the legal and social status of women. For further reading on the Hudood Ordinances, see ASMA JAHANGIR and HINA JILANI, The Hudood Ordinances: A Divine Sanction? (1990) and C.H. KENNEDY, 'Islamisation in Pakistan: Implementation of the Hudood Ordinances', 18 Asian Survey No. 3 (1988) 307-316.

${ }^{64}$ D. KANDIYOTI, op. cit. n. 62 , p. 6.

${ }^{65}$ Loc. cit. n. 4.

${ }^{66}$ The justification for section 17 purports to have its basis in verse 282:2 of the Quran, which says: "[. . .] believers, when you negotiate a debt for a fixed term, draw up an agreement in writing [ . . .] and have two of your men to act as witnesses; but if two men are not available, then a man and two women you approve, so that in case one of them is confused the other may remind her". 
again, a woman's inherent weakness and presumed tendency to forgetfulness is invoked to justify the enactment of protective legislation.

\section{CONCLUDING REMARKS}

An analysis of state practice reveals a highly protective approach to women's participation in paid employment, an approach that is clearly sanctioned by constitutional doctrine. Domestic legislation referring specifically to women workers is almost exclusively protective in nature. Although Pakistan is a party to the 1958 ILO Discrimination (Employment and Occupation) Convention, as yet no legislation on equal treatment or equal pay within the workforce exists. Neither has any legislation been enacted to give effect to the constitutional norm of non-discrimination on the basis of sex. The development of international law in this field has had very little impact within Pakistan. The movement away from gender-specific protective measures within international law has not been followed by Pakistan, and the international legislation which has been ratified by it allows this protective approach to remain intact. The existence of gender-specific protective legislation has not encountered much opposition. Indeed more stringent enforcement measures have been demanded. ${ }^{67}$ This arises from the desire to reduce the incidence of exploitative and objectionable work practices. As BEATRICE WEBB so succinctly put it when writing on nineteenth century protective legislation in the UK, "Not exclusion but exploitation is the problem here". ${ }^{68}$ Securing women's formal equality by abolishing protective legislation merely yields to the prevailing male norms of the workplace and severely disadvantages women, pregnant women in particular, who do not 'fit' easily into existing structures. A preferable approach would be to improve the position of all workers by extending the cover of protective legislation to male as well as female

Section 17 of the Law of Evidence Order 1984, has been strongly criticised as being a misinterpretation of the Quranic verse, as the latter relates only to monetary notes or debt notes. Its suggestions for witness requirements are recommendatory only, not mandatory, and it provides no justification for widening the ambit of section 17 of the Evidence Order to include financial or future obligations. Further, there is a jurisprudential debate as to whether the Quranic verse, emanating from the Medina period, has been superseded by other verses relating to the competence of men and women to give evidence, which were revealed at a later date.

${ }^{67}$ See generally, Proceedings of the Workshop on Women and Employment Legislation in Pakistan organised by the British Council in collaboration with the Ministry of Women Development, Lahore, 1993.

${ }^{68}$ B. WEBB (ed.), The Case for the Factory Acts (1901). 
employees, ${ }^{69}$ following the approach adopted by the UN in the Women's Convention, while at the same time strengthening the present system of maternity protection to ensure security of employment for pregnant women and greater control and decision-making powers for women within that system. This would tackle the gender-specificity of protective legislation without ignoring the potential for exploitation within the workforce.

${ }^{69}$ Much of the trade union support for factory reforms in the UK in the late nineteenth century was based on the hope that protections already won for women and children would eventually be extended to cover male workers also. As the WEBBS so shrewdly commented, "The battle was fought from behind the women's petticoats". SIDNEY and BEATRICE WEBB, History of Trade Unionism (1894; 1907 edition) 297. 